\title{
Probiotics in Inflammatory Bowel Disease: Are We Back to Square One?
}

\author{
Suvarna Rekha Puvvada ${ }^{1}$, Enkhmaa Luvsannyam ${ }^{2}$, Dhara Patel ${ }^{3}$, Zaira Hassan ${ }^{1}$, Pousette Hamid ${ }^{4}$ \\ 1. Internal Medicine, California Instititute of Behavioral Neurosciences \& Psychology, Fairfield, USA 2. Plastic Surgery, \\ California Instititute of Behavioral Neurosciences \& Psychology, Fairfield, USA 3. Family Medicine, California \\ Instititute of Behavioral Neurosciences \& Psychology, Fairfield, USA 4. Neurology, California Instititute of Behavioral \\ Neurosciences \& Psychology, Fairfield, USA
}

Corresponding author: Suvarna Rekha Puvvada, suvarna.korpu@gmail.com

\begin{abstract}
Inflammatory bowel disease (IBD) is a chronic inflammatory condition of the alimentary tract whose incidence has been increasing over the past few years. Even though there is a complex interplay of several factors in the pathogenesis of IBD, a decrease in the diversity of intestinal microbiome is commonly found in patients. Extensive research is directed towards the alteration of this microbiome to improve the symptoms of IBD. Probiotics, prebiotics, antibiotics, and diet are studied in this regard extensively. Among them, probiotics have gained more interest as some of the studies showed them to be effective in decreasing gut inflammation in vitro and in vivo. Although there is no cure for IBD as of today, the available medications do decrease gut inflammation and help prolong remission and decrease relapse rates. But their side effects preclude their long-term use. Probiotics may be a ray of hope among IBD patients as they are apparently safe. This article reviews each of the available literature from the past 10 years to see if there is any certain role of probiotics in induction, maintenance of remission, prevention of relapse, and improvement in the quality of life in IBD patients.
\end{abstract}

Categories: Internal Medicine, Gastroenterology

Keywords: ibd, probiotics, microbiome

\section{Introduction And Background}

Inflammatory bowel disease (IBD), which consists of two patterns, ulcerative colitis (UC) and Crohn's disease (CD), is a chronic inflammatory condition. The etiology of IBD is multifactorial. Genetics, immunological and environmental factors along with disturbances in the intestinal barrier are implicated in the pathogenesis of IBD [1]. Out of these, environmental factors like smoking, diet, microbiota, and medications are modifiable and have been extensively studied in recent times [1]. The reason for this growing interest is, despite the advances in genetics, only about $25 \%$ of IBD cases are known to be heritable. The epidemiological trends in developing countries after industrialization suggest that environmental factors may play a pivotal role in causing intestinal inflammation in genetically susceptible individuals [2,3]. Second, dysbiosis is documented to play a major role in IBD pathogenesis [4]. Ever since studies on dysbiosis as a cause for IBD started blooming, researchers parallelly have been studying the factors that could modify the microbiome. Third, though the available drug therapies, which work by blocking the immune system, are shown to be effective in remission of IBD, there has been a concern regarding their side effects [5]. Also, gut microbiota, along with taking part in pathogenesis, influence the efficacy of certain drug therapies, such as anti-tumor necrosis factor- $\alpha$ (anti-TNF- $\alpha$ ), steroids, etc. [6,7]. So there is a constant search for therapies that would induce and continue remission in IBD patients with minimum side effects. In this regard, probiotics have gained interest in recent times.

Probiotics by definition are living microorganisms that exert beneficial effects on the host by modifying the intestinal microbiota [8]. Since the first-ever concept of probiotic in the 20th century as speculated by Metchnikoff, that life could be prolonged by manipulating the intestinal microbiome with friendly bacteria Lactobacillus bulgaricus found in yogurt, a lot of light has been shed on the mechanism of action of probiotics [9]. It has been proved that once ingested, probiotics work by decreasing harmful microbiota, increasing protective microbiota, improving gut epithelial barrier function by producing various metabolites like short-chain fatty acids, and modulating the immune system [10].

There is always a debate regarding the benefit of probiotic usage in IBD patients. A meta-analysis conducted by Ganji-Arjenaki and Rafieian-Kopaei showed the efficacy of probiotics in UC, but not in CD [11]. Another meta-analysis done by Derwa et al. concluded that probiotics are as effective as 5-aminosalicylic acid (5ASA) in preventing relapse in inactive UC and the probiotic VSL\#3 is especially effective in inducing remission in UC patients [12]. A study conducted by Cordina et al. showed that probiotics are popularly being prescribed by physicians in patients with gastrointestinal disorders, especially in IBD [13]. Many commercial over-the-counter food products that claim to contain probiotics are extremely popular among the public. In this regard, we are trying to identify and review the available data from the past 10 years and give a bird's eye view on the usage of probiotics in IBD. By this review, we aim to answer a few questions such as whether 


\section{Cureus}

probiotics are effective in achieving remission, preventing relapse, and decreasing symptoms/inflammation in IBD. If so, whether they are equally useful in various types of IBD, and also, the desired direction of future studies.

\section{Review}

We conducted a search of the literature in PubMed, Google Scholar, and Medical Subject Headings (MeSH) on Demand using search terms such as probiotics, ulcerative colitis, Crohn's disease, and inflammatory bowel disease. The studies included are randomized control trials including adults (age $>18$ years) with active or quiescent IBD, using either single- or multi-strain probiotics compared to placebo, assessing the outcome measure of remission, relapse, or quality of life (QOL) in the past 10 years. Animal studies, studies with population aged $<18$ years, and studies not measuring the above-mentioned outcomes were excluded from this review.

Our search got us 13 relevant studies that we reviewed in this article. The included studies $(n=13)$ are summarised in Table 1 .

\begin{tabular}{|c|c|c|c|c|c|c|c|c|}
\hline $\begin{array}{l}\text { Author and } \\
\text { year }\end{array}$ & Location & Disease & Pattern & Probiotic used & $\begin{array}{l}\text { Dose of } \\
\text { probiotic }\end{array}$ & Intervention & $\begin{array}{l}\text { Duration } \\
\text { of } \\
\text { probiotic } \\
\text { given }\end{array}$ & Results \\
\hline $\begin{array}{l}\text { Yilmaz et } \\
\text { al., } 2019 \\
{[14]}\end{array}$ & Turkey & $\begin{array}{l}\text { UC and } \\
C D\end{array}$ & Active & $\begin{array}{l}\text { Kefir ( } 1 \mathrm{ml} \text { contains } 2 \mathrm{x} \\
10^{10} \mathrm{CFU} \text { Lactobacillus) }\end{array}$ & $\begin{array}{l}400 \mathrm{ml} \\
\text { twice a } \\
\text { day }\end{array}$ & $\begin{array}{l}\text { Probiotic vs } \\
\text { respective } \\
\text { disease } \\
\text { controls }\end{array}$ & 4 weeks & $\begin{array}{l}\text { Statistically significant } \\
\text { increases in the } \\
\text { Lactobacillus load in both } \\
\text { UC and CD patients; a } \\
\text { decrease in CRP, ESR, } \\
\text { bloating scores and an } \\
\text { increase in Hb, feeling } \\
\text { good scores in the } \\
\text { probiotic arm }\end{array}$ \\
\hline $\begin{array}{l}\text { Bjarnason } \\
\text { et al., } 2019 \\
\text { [15] }\end{array}$ & $\begin{array}{l}\text { United } \\
\text { Kingdom }\end{array}$ & $\begin{array}{l}\text { UC and } \\
C D\end{array}$ & $\begin{array}{l}\text { Quiescent } \\
\text { or mild } \\
\text { active }\end{array}$ & $\begin{array}{l}\text { Symprove }{ }^{\mathrm{TM}} \\
\text { (Lactobacillus plantarum } \\
\text { NCIMB } 30173 \text {, } \\
\text { Lactobacillus rhamnosus } \\
\text { NCIMB } 30174 \text {, } \\
\text { Lactobacillus acidophilus } \\
\text { NCIMB } 30175 \text { and } \\
\text { Enterococcus faecium } \\
\text { NCIMB } 30176 \text { ) }\end{array}$ & $\begin{array}{l}1 \\
\mathrm{ml} / \mathrm{kg} / \mathrm{day}\end{array}$ & $\begin{array}{l}\text { Probiotic vs } \\
\text { placebo }\end{array}$ & 4 weeks & $\begin{array}{l}\text { No difference in IBD QOL in } \\
\text { both arms. FCAL levels } \\
\text { decreased in UC but not in } \\
\text { CD compared to placebo. }\end{array}$ \\
\hline $\begin{array}{l}\text { Matsuoka } \\
\text { et al., } 2018 \\
{[16]}\end{array}$ & Japan & UC & Inactive & $\begin{array}{l}\text { Lactobacillus acidophilus } \\
\text { ( } 1 \text { billion bacteria) and } \\
\text { Bifidobacterium breve } \\
\text { strain Yakult ( } 10 \text { billion } \\
\text { bacteria) }\end{array}$ & $\begin{array}{l}100 \\
\mathrm{ml} / \text { day }\end{array}$ & $\begin{array}{l}\text { Probiotic vs } \\
\text { placebo }\end{array}$ & 48 weeks & $\begin{array}{l}\text { There was no significant } \\
\text { difference in relapse-free } \\
\text { intervals nor the incidence } \\
\text { of relapse in both arms. }\end{array}$ \\
\hline $\begin{array}{l}\text { Vejdani et } \\
\text { al., } 2017 \\
{[17]}\end{array}$ & Iran & UC & $\begin{array}{l}\text { Active } \\
\text { Mild to } \\
\text { moderate }\end{array}$ & $\begin{array}{l}\text { Lactobacillus casei ATCC } \\
\text { PTA-3945 capsule ( } 5 x \\
10^{5} \text { organisms) }\end{array}$ & $\begin{array}{l}\text { One } \\
\text { capsule } \\
\text { twice a } \\
\text { day }\end{array}$ & $\begin{array}{l}\text { Probiotic vs } \\
\text { placebo }\end{array}$ & 8 weeks & $\begin{array}{l}\text { No significant difference in } \\
\text { remission and relapse rates } \\
\text { between two arms }\end{array}$ \\
\hline $\begin{array}{l}\text { Tamaki et } \\
\text { al., } 2016 \\
{[18]}\end{array}$ & Japan & UC & Active & $\begin{array}{l}\text { Bifidobacterium longum } \\
536 \text { (BB536 2-3 x 1011 } \\
\text { organisms) }\end{array}$ & $\begin{array}{l}\text { Three } \\
\text { times a } \\
\text { day }\end{array}$ & $\begin{array}{l}\text { Probiotic vs } \\
\text { placebo }\end{array}$ & 8 weeks & $\begin{array}{l}\text { No statistically significant } \\
\text { change in remission rates in } \\
\text { two arms; significant } \\
\text { decrease in UCDAl scores, } \\
\text { Rachmilewitz El, and Mayo } \\
\text { sub-score in the probiotic } \\
\text { arm }\end{array}$ \\
\hline $\begin{array}{l}\text { Yoshimatsu } \\
\text { et al., } 2015 \\
\text { [19] }\end{array}$ & Japan & UC & Inactive & $\begin{array}{l}\text { Bio-Three tablet ( } 10 \mathrm{mg} \\
\text { of Clostridium } \\
\text { butyricum TO-A, } 2 \mathrm{mg} \text { of } \\
\text { Streptococcus faecalis T- } \\
110 \text {, and } 10 \mathrm{mg} \text { of } \\
\text { Bacillus }\end{array}$ & $\begin{array}{l}\text { Three } \\
\text { tablets } \\
\text { three } \\
\text { times a } \\
\text { day }\end{array}$ & $\begin{array}{l}\text { Probiotic vs } \\
\text { placebo }\end{array}$ & $\begin{array}{l}12 \\
\text { months }\end{array}$ & $\begin{array}{l}\text { Significantly fewer relapse } \\
\text { rates in the probiotic arm at } \\
3 \text { and } 6 \text { months; no } \\
\text { significant difference in } \\
\text { remission rates at } 12 \\
\text { months in both arms }\end{array}$ \\
\hline
\end{tabular}




\section{Cureus}

\begin{tabular}{|c|c|c|c|c|c|c|c|c|}
\hline & & & & mesentericus TO-A) & & & & \\
\hline $\begin{array}{l}\text { Fedorak et } \\
\text { al., } 2015 \\
\text { [20] }\end{array}$ & Canada & CD & $\begin{array}{l}\text { Post- } \\
\text { surgery }\end{array}$ & $\begin{array}{l}\text { strains of Lactobacillus, } \\
\text { three strains } \\
\text { of Bifidobacterium, and } \\
\text { one strain } \\
\text { of Streptococcus } \\
\text { salivarius subspecies } \\
\text { thermophilus) }\end{array}$ & $\begin{array}{l}\text { One } \\
\text { sachet } \\
\text { twice a } \\
\text { day }\end{array}$ & $\begin{array}{l}\text { Probiotic vs } \\
\text { placebo }\end{array}$ & 365 days & $\begin{array}{l}\text { No statistically significant } \\
\text { difference in recurrence } \\
\text { rates and severity } \\
\text { proportion at } 90 \text { days in } \\
\text { two arms and also } \\
\text { aggregate severe } \\
\text { recurrence rates at } 365 \\
\text { days; statistically } \\
\text { significant decrease in } \\
\text { mucosal inflammatory } \\
\text { cytokine levels in the VSL\#3 } \\
\text { arm at } 90 \text { days }\end{array}$ \\
\hline $\begin{array}{l}\text { Petersen et } \\
\text { al., 2014 } \\
\text { [21] }\end{array}$ & Denmark & UC & Active & $\mathrm{EcN}$ & $\begin{array}{l}100 \mathrm{mg} \\
\text { once a } \\
\text { day for } \\
\text { four days } \\
\text { followed } \\
\text { by } 100 \\
\text { mg twice } \\
\text { a day }\end{array}$ & $\begin{array}{l}\text { Ciprofloxacin/ } \\
\text { placebo for } \\
\text { one week } \\
\text { followed by } \\
\text { EcN/placebo } \\
\text { for seven } \\
\text { weeks }\end{array}$ & 7 weeks & $\begin{array}{l}\text { Statistically significant } \\
\text { fewer remission rates and } \\
\text { lack of mucosal healing in } \\
\text { placebo followed by EcN } \\
\text { compared to other groups. } \\
\text { Groups receiving EcN } \\
\text { reached remission less } \\
\text { frequently than groups not } \\
\text { receiving EcN }\end{array}$ \\
\hline $\begin{array}{l}\text { Bourreille } \\
\text { et al., 2013 } \\
\text { [22] }\end{array}$ & France & $\begin{array}{l}\text { Crohn's } \\
\text { disease }\end{array}$ & Inactive & Saccharomyces boulardii & $1 \mathrm{~g} /$ day & $\begin{array}{l}\text { Probiotic vs } \\
\text { placebo }\end{array}$ & 52 weeks & $\begin{array}{l}\text { No statistically significant } \\
\text { difference in mean CDAl } \\
\text { scores, ESR, or CRP at } 52 \\
\text { weeks. No beneficial } \\
\text { effects of the probiotic }\end{array}$ \\
\hline $\begin{array}{l}\text { Wildt et al., } \\
2011 \text { [23] }\end{array}$ & Italy & UC & Inactive & $\begin{array}{l}\text { Probio-Tec AB- } 25 \\
\text { capsule }\left(1.25 \times 10^{10} \mathrm{CFU}\right. \\
\text { of Bifidobacterium } \\
\text { animalis strain BB-12 and } \\
1.25 \times 10^{10} \mathrm{CFU} \text { of } \\
\text { Lactobacillus acidophilus } \\
\text { strain La-5) }\end{array}$ & $\begin{array}{l}\text { Two } \\
\text { capsules } \\
\text { three } \\
\text { times a } \\
\text { day }\end{array}$ & $\begin{array}{l}\text { Probiotic vs } \\
\text { placebo }\end{array}$ & 52 weeks & $\begin{array}{l}\text { No statistically significant } \\
\text { difference in remission after } \\
\text { one year and relapse rates } \\
\text { in two arms }\end{array}$ \\
\hline $\begin{array}{l}\text { Tursi et al., } \\
2010 \text { [24] }\end{array}$ & Italy & UC & Active & VSL\#3 & $\begin{array}{l}\text { Two } \\
\text { sachets } \\
\text { twice a } \\
\text { day }\end{array}$ & $\begin{array}{l}\text { Probiotic vs } \\
\text { placebo }\end{array}$ & 8 weeks & $\begin{array}{l}\text { Statistically significant } \\
\text { improvement of at least } \\
50 \% \text { in UCDAl scores and a } \\
\text { decrease in UCDAI scores } \\
\text { from baseline in the } \\
\text { probiotic arm; no } \\
\text { statistically significant } \\
\text { difference in the induction } \\
\text { of remission in two arms }\end{array}$ \\
\hline $\begin{array}{l}\mathrm{Ng} \text { et al., } \\
2010 \text { [25] }\end{array}$ & $\begin{array}{l}\text { United } \\
\text { Kingdom }\end{array}$ & UC & Active & VSL\#3 & $\begin{array}{l}\text { Two } \\
\text { sachets } \\
\text { twice a } \\
\text { day }\end{array}$ & $\begin{array}{l}\text { Probiotic vs } \\
\text { placebo }\end{array}$ & 8 weeks & $\begin{array}{l}\text { Statistically significant } \\
\text { decrease in intestinal DC } \\
\text { TLR-2 expression, IL-12p40 } \\
\text { production and an increase } \\
\text { in IL-10 production }\end{array}$ \\
\hline $\begin{array}{l}\text { Matthes et } \\
\text { al., 2010 } \\
\text { [26] }\end{array}$ & Germany & UC & Active & $\begin{array}{l}\text { EcN } 1917 \\
\left(10^{8} \text { organisms } / \mathrm{ml}\right)\end{array}$ & $\begin{array}{l}10,20,40 \\
\mathrm{ml} \\
\text { enemas }\end{array}$ & $\begin{array}{l}\text { Probiotic vs } \\
\text { placebo }\end{array}$ & 12 weeks & $\begin{array}{l}\text { No statistically significant } \\
\text { difference in the number of } \\
\text { responders (DAI<2) in both } \\
\text { arms after ITT analysis. } \\
\text { Statistically significant } \\
\text { dose-dependent efficacy } \\
\text { was noted in per-protocol } \\
\text { response rates. }\end{array}$ \\
\hline
\end{tabular}

\section{TABLE 1: Summary of included studies ( $n=13)$}

UC: ulcerative colitis; CD: Crohn's disease; CFU: colony-forming unit; CRP: C-reactive protein; ESR: erythrocyte sedimentation rate; Hb: 


\section{Cureus}

hemoglobin; IBD: inflammatory bowel disease; QOL: quality of life; FCAL: fecal calprotectin; UCDAl: Ulcerative Colitis Disease Activity Index; EcN: Escherichia coli Nissle; CDAI: Crohn's Disease Activity Index; DC: dendritic cell; TLR: Toll-like receptor; IL: interleukin; ITT: intention to treat; DAI: disease activity index; El: endoscopic index; CFU: colony-forming unit

As IBD has no effective cure as of today, patients often resort to all available alternative treatments for this chronic illness. Probiotics happen to be the most commonly used alternative products for IBD treatment. Studies show that an estimated 3.9 million American adults used probiotics and prebiotics in the year 2015, which is four times that used in the year 2007 [27,28]. There is no strict regulation on the marketing of these over-the-counter products as they are considered as food products but not as medication by US FDA [29].

\section{Efficacy of probiotics in induction, maintenance of remission, and prevention of relapse in UC}

Traditionally, anti-inflammatory medications have been used for the induction and maintenance of remission in UC patients. The 5-ASA class of medications has been used as the first-line medication for the induction of remission in mild to moderate cases. Since the evolution of the concept of probiotics, they have been studied as a safe alternative. $\mathrm{Ng}$ et al. conducted a study with 28 active UC patients who were randomized to either VSL\#3 or placebo groups for eight weeks. The results showed that 10 of 14 and 5 of 14 achieved clinical response in probiotic and placebo groups, respectively, but the difference was not statistically significant [25]. Matthes et al. randomized 90 UC patients with the active disease into Escherichia coli Nissle (EcN) and placebo groups. Treatments were given through enemas for two weeks and the patients were followed for eight weeks. EcN was given in doses of 10, 20, and $40 \mathrm{ml}$. They did not find any statistically significant difference in the number of responders (disease activity index<2) in both arms after intention-to-treat (ITT) analysis ( $\mathrm{p}=0.4430$, two-sided). Statistically significant dose-dependent efficacy was noted in per-protocol respond rates: EcN $40 \mathrm{ml}, 52.9 \%$; $20 \mathrm{ml}, 44.4 \% ; 10 \mathrm{ml}$, 27.3\%; placebo, $18.2 \%$ ( $p=0.0446$, two-sided) [26]. Tamaki et al. conducted a study on mild to moderate UC patients and found that there was a significant decrease in Ulcerative Colitis Disease Activity Index (UCDAI) scores in the Bifidobacterium longum (BB536) group from baseline after eight weeks $(\mathrm{p}<0.01)$, but this was not seen in the placebo group ( $\mathrm{p}=0.88$ ). Also, the Rachmilewitz endoscopic score and Mayo sub-score were significantly decreased in the probiotic arm but not in the placebo arm. However, the clinical remission defined as UCDAI $<2$ at eight weeks did not differ in the probiotic versus placebo group (63\% vs 52\%, p=0.395) [18]. Vejdani et al. conducted a study on mild to moderate UC patients by randomizing them to Lactobacillus casei or placebo group while continuing the conventional therapy in both the groups. They found that there is no significant difference between probiotic versus placebo group in remission rates ( $82 \%$ vs $76 \%$ at ITT analysis, $p=1.00$, and $100 \%$ vs $81.2 \%$ at per-protocol analysis, $\mathrm{p}=0.23)$ and relapse rates $(14.3 \%$ vs $26.7 \%$ at ITT, $\mathrm{p}=0.65$, and $16.7 \%$ vs $33.3 \%$ at per-protocol analysis, $\mathrm{p}=0.64$ ). The same was the case with the mean time to remission and relapse between the two groups ( $\mathrm{p}=0.11$ and $\mathrm{p}=0.51$ ) [17]. Wildt et al. conducted a study in UC patients in remission using Probio-Tec AB-25 and concluded that there was no significant difference in the percentage of patients maintaining remission after one year in the probiotic versus placebo group (25\% vs $8 \%, \mathrm{p}=0.37$ ) and also in median time to relapse (125.5 days vs 104 days, $\mathrm{p}=0.683$ ) [23]. Matsuoka et al. randomized 195 patients with quiescent UC into BFM fermented milk or placebo groups for 48 weeks. They did an interim analysis and the results showed no significant difference in the incidence of relapse or relapse-free survival ( $\mathrm{p}=0.643$, a hazard ratio of $1.16 \%$ with $95 \%$ CI $0.63-2.14$, log-rank test) or maintenance of remission between two arms. They couldn't find any effect of probiotics on intestinal microbiota as evident from fecal samples [16]. Tursi et al. conducted a study on 65 active UC patients randomizing them to VSL $\# 3$ or probiotic. The UDAI scores greater than or equal to $50 \%$ were more in the probiotic compared to the placebo group (63.1 vs 40.8; per-protocol p=0.010, 95\% CI 0.51-0.74; ITT). A significant improvement of the UDAI score greater than or equal to 3 was seen in the VSL\#3 group ( $p=0.017)$. At the same time, no difference was seen in the rate of disease activity and endoscopic scores in both groups. Though the remission rates were higher in the VSL\#3 group, it was not statistically significant [24].

In contrast to the above-mentioned studies, a study done by Yoshitmasu et al. in $60 \mathrm{UC}$ patients in remission using Bio-Three and placebo for 12 months showed that by the end of three months, the relapse rates in Bio-Three were less compared to placebo ( $0.0 \%$ vs $17.4 \%, \mathrm{p}=0.036)$, but there was no difference at six and nine months. There was no difference in remission rates at 12 months between Bio-Three (69.5\%) and placebo (56.6\%) groups, $\mathrm{p}=0.248$ [19]. Another study was done by Peterson et al. in patients with active UC, where patients were initially randomized into ciprofloxacin or placebo group for one week followed by EcN or placebo for seven weeks. They found that patients who received placebo/EcN had lesser remission compared to the placebo/placebo group (54\% vs $89 \%$, p<0.05). Also, the placebo/EcN group had significantly more number of withdrawals, 11/25 (44\%) compared to other groups 15/75 (20\%), p<0.05. Mucosal healing in placebo/EcN (29\%) was less compared to other groups $(\mathrm{p}<0.05)$ [21].

We found that most of the studies showed that probiotics have no role in achieving remission in UC patients. Although there was a decrease in disease activity index scores compared to baseline in a few studies, there appears to be no significant decrease to meet the criteria to define remission. The relapse rates and relapsefree intervals are also not affected by probiotics. 


\section{Efficacy of probiotics in relapse in CD}

There is very little data available on the role of probiotics in the relapse of $\mathrm{CD}$. The clinical and endoscopic relapse rates for low versus high-risk CD 18 months after surgery are 20 and 30 versus 50 and 80, respectively [30]. Fedorak et al. conducted a study in CD patients within 30 days of ileocolic resection and anastomosis assigning them to the VSL\#3 or placebo group. Endoscopy was done at 90 days and they found that there is no difference between VSL\#3 and placebo groups in terms of percentage of patients with severe endoscopic lesions ( $9.3 \%$ vs $15.7 \%$, $\mathrm{p}=0.19$ ). The patients with no or mild endoscopic lesions at 90 days from both the groups who were continued with probiotics till 365 days and who had severe endoscopic lesions at 365 days showed no difference between early versus late starters of probiotics ( $10 \%$ vs $26.7 \%, \mathrm{p}=0.09$ ). Also, there was no significant difference in aggregate severe recurrence rates on 90 and 365 days as evidenced by $20.5 \%$ and $42.1 \%$ of subjects in the early versus late VSL $\# 3$ group, respectively [20]. Bourreille et al. conducted a study on $165 \mathrm{CD}$ patients who were on remission and randomized them to either Saccharomyces boulardii or placebo group for 52 weeks. They found that there was no significant difference between the probiotic versus placebo group in the percentage of relapse ( $47.5 \%$ vs $53.2 \%)$, the median time to relapse (40.7 vs 39 weeks), CD activity index scores, erythrocyte sedimentation rate, and median Creactive protein (CRP) levels [22].

As only two out of 13 studies were done on the efficacy of probiotics in relapse of $\mathrm{CD}$, it is to be noted that there is not much evidence to support any role of probiotics in decreasing relapses in CD.

\section{Efficacy of probiotics in QOL in IBD patients}

Improvement in QOL is an important aspect of the treatment of IBD patients. Patients with active disease have a poor QOL regardless of the disease subtype. Yilmaz et al. conducted a study using probiotic kefir on 45 active IBD patients ( 25 in the treatment group and 20 in the control group), out of which 25 were UC and $22 \mathrm{CD}$. They observed a significant increase in the Lactobacillus load in feces of both UC $(\mathrm{p}=0.001)$ and CD $(\mathrm{p}=0.005)$ patients by four weeks. In patients with $\mathrm{CD}$, there was a significant reduction in bloating $(\mathrm{p}=0.012)$ and improvement in feeling good scores $(\mathrm{p}=0.032)$ in the last two weeks, a decrease in CRP levels $(\mathrm{p}=0.015)$, and an increase in hemoglobin levels $(\mathrm{p}=0.024)$ at four weeks in the kefir group. They also found that the rate of feeling good score in CD was significantly more compared to UC $(\mathrm{p}=0.019)$ [14]. In a study by Bjarnason et al., $81 \mathrm{UC}$ and $61 \mathrm{CD}$ patients were randomized to receive either Symprove ${ }^{\mathrm{TM}}$ (Symprove Ltd, Farnham, UK) or placebo for four weeks. They observed no significant change in IBD QOL and clinical disease activity before and after treatment between the probiotic and placebo groups. A post hoc analysis of fecal calprotectin levels in the probiotic group showed a significant decrease $(\mathrm{p}=0.011$, for $\mathrm{t}$-test, and $\mathrm{p}=0.001$, for Wilcoxon's) after four weeks in UC but not CD patients. There were $0 / 40$ relapses in the probiotic arm and $4 / 41$ relapses in the placebo arm in UC patients. There were no relapses seen in CD patients in both arms [15]. Fedorak et al. found that the patients on VSL $\# 3$ had decreased mucosal inflammatory cytokines at day 90 compared to the placebo group ( $\mathrm{p}<0.05$ ). They also noticed that the CD activity index and IBD QOL were similar in VSL\#3 and placebo groups [20]. Ng et al. found significant decreases in dendritic cell Toll-like receptor-2 expression $(\mathrm{p}<0.05)$ and proinflammatory cytokine interleukin-12p40 production $(\mathrm{p}<0.05)$ in the VSL\#3 arm, which was not seen in placebo [25].

Two out of three studies showed improvement and one showed no change in QOL in IBD patients. Based on these findings, we can say that probiotics might have a positive effect on QOL in patients with IBD.

\section{Limitations}

Each of the studies was conducted on small populations over a short duration of time. These factors ultimately affect the power of the study. Also, there is no consistency in strains, their doses, and route of administration in these studies that precludes us from combining these results. We included studies from the past 10 years and could have missed data from previous years.

\section{Future directions}

Future randomized control trials should aim to design a protocol to test the efficacy of individual probiotic strains by conducting larger trials in different ethnic groups to identify the doses that will modify the microbiome and then combine the results to formulate a guideline for their use in IBD. This requires an immense amount of testing, time, funding, and regulation on the usage of probiotics. We hope to find answers for a few questions in the future, such as what is the bioavailability of the probiotics? Which route of administration is better? What is the exact pathogenesis of IBD that causes a change in the microbiome? How does a combination of different strains affect the efficacy of individual strain?

\section{Conclusions}

The relationship between the intestinal microbiome and its host is complex. Probiotics have the ability to manipulate the environment of the intestinal microbiome by their competitive nature to eliminate pathogens. Previous studies show that they have anti-inflammatory and immunomodulatory effects, but their results in IBD remission and relapse are heterogeneous and inconsistent. Although probiotics are considered a safe complementary treatment for IBD, their effect on induction, maintaining remission and 
relapse is questionable even today as there is no strong evidence supporting their use. Therefore, this leaves us with the fact that the same questions are staring at us for definitive answers after all these years.

\section{Additional Information \\ Disclosures}

Conflicts of interest: In compliance with the ICMJE uniform disclosure form, all authors declare the following: Payment/services info: All authors have declared that no financial support was received from any organization for the submitted work. Financial relationships: All authors have declared that they have no financial relationships at present or within the previous three years with any organizations that might have an interest in the submitted work. Other relationships: All authors have declared that there are no other relationships or activities that could appear to have influenced the submitted work.

\section{References}

1. Ramos GP, Papadakis KA: Mechanisms of disease: inflammatory bowel diseases . Mayo Clin Proc. 2019, 94:155-165. 10.1016/j.mayocp.2018.09.013

2. Ng SC, Shi HY, Hamidi N, et al.: Worldwide incidence and prevalence of inflammatory bowel disease in the 21st century: a systematic review of population-based studies. Lancet. 2018, 390:2769-2778. 10.1016/S0140-6736(17)32448-0

3. Shouval DS, Rufo PA: The role of environmental factors in the pathogenesis of inflammatory bowel disease: a review. JAMA Pediatr. 2017, 171:999-1005. 10.1001/jamapediatrics.2017.2571

4. Nishida A, Inoue R, Inatomi O, Bamba S, Naito Y, Andoh A: Gut microbiota in the pathogenesis of inflammatory bowel disease. Clin J Gastroenterol. 2018, 11:1-10. 10.1007/s12328-017-0813-5

5. Ko CW, Singh S, Feuerstein JD, et al.: AGA clinical practice guidelines on the management of mild-tomoderate ulcerative colitis. Gastroenterology. 2019, 156:748-764. 10.1053/j.gastro.2018.12.009

6. Aden K, Rehman A, Waschina S, et al.: Metabolic functions of gut microbes associate with efficacy of tumor necrosis factor antagonists in patients with inflammatory bowel diseases. Gastroenterology. 2019, 157:1279-1292.E11. 10.1053/j.gastro.2019.07.025

7. Michail S, Durbin M, Turner D, et al.: Alterations in the gut microbiome of children with severe ulcerative colitis. Inflamm Bowel Dis. 2012, 18:1799-1808. 10.1002/ibd.22860

8. Schrezenmeir J, de Vrese M: Probiotics, prebiotics, and synbiotics - approaching a definition . Am J Clin Nutr. 2001, 73:361s-364s. 10.1093/ajcn/73.2.361s

9. Metchnikoff E: Lactic acid as inhibiting intestinal putrefaction. In The Prolongation of Life: Optimistic Studies. Mitchell PC (ed): Putnam's Sons, New York; 1908. 161-183.

10. Oka A, Sartor RB: Microbial-based and microbial-targeted therapies for inflammatory bowel diseases . Dig Dis Sci. 2020, 65:757-788. 10.1007/s10620-020-06090-z

11. Ganji-Arjenaki M, Rafieian-Kopaei M: Probiotics are a good choice in remission of inflammatory bowel diseases: a meta-analysis and systematic review. J Cell Physiol. 2018, 233:2091-2103. 10.1002/jcp.25911

12. Derwa Y, Gracie DJ, Hamlin PJ, Ford AC: Systematic review with meta-analysis: the efficacy of probiotics in inflammatory bowel disease. Aliment Pharmacol Ther. 2017, 46:389-400. 10.1111/apt.14203

13. Cordina C, Shaikh I, Shrestha S, Camilleri-Brennan J: Probiotics in the management of gastrointestinal disease: analysis of the attitudes and prescribing practices of gastroenterologists and surgeons. J Dig Dis. 2011, 12:489-496. 10.1111/j.1751-2980.2011.00534.x

14. Yilmaz I, Dolar ME, Ozpinar H: Effect of administering kefir on the changes in fecal microbiota and symptoms of inflammatory bowel disease: a randomized control trial. Turk J Gastroenterol. 2019, 30:242253. 10.5152/tjg.2018.18227

15. Bjarnason I, Sission G, Hayee B: A randomized, double-blind, placebo-controlled trial of a multi-strain probiotic in patients with asymptomatic ulcerative colitis and Crohn's disease. Inflammopharmacology. 2019, 27:465-473. 10.1007/s10787-019-00595-4

16. Matsuoka K, Uemura Y, Kanai T, et al.: Efficacy of Bifidobacterium breve fermented milk in maintaining remission of ulcerative colitis. Dig Dis Sci. 2018, 63:1910-1919. 10.1007/s10620-018-4946-2

17. Vejdani R, Bahari A, Masjedi Zadeh A, et al.: Effects of Lactobacillus casei probiotic on mild to moderate ulcerative colitis: a placebo-controlled study. Indian J Med Sci. 2017, 69:24-28. 10.18203/issn.00195359.IndianJMedSci20170486

18. Tamaki H, Nakase H, Inoue S, et al.: Efficacy of probiotic treatment with Bifidobacterium longum 536 for induction of remission in active ulcerative colitis: a randomized, double-blinded, placebo-controlled multicenter trial. Dig Endosc. 2016, 28:67-74. 10.1111/den.12553

19. Yoshimatsu Y, Yamada A, Furukawa R, et al.: Effectiveness of probiotic therapy for the prevention of relapse in patients with inactive ulcerative colitis. World J Gastroenterol. 2015, 21:5985-5994. 10.3748/wjg.v21.i19.5985

20. Fedorak RN, Feagan BG, Hotte N, et al.: The probiotic VSL\#3 has anti-inflammatory effects and could reduce endoscopic recurrence after surgery for Crohn's disease. Clin Gastroenterol Hepatol. 2015, 13:928-935.E2. 10.1016/j.cgh.2014.10.031

21. Petersen AM, Mirsepasi H, Halkær SI, Mortensen EM, Nordgaard-Lassen I, Krogfelt KA: Ciprofloxacin and probiotic Escherichia coli Nissle add-on treatment in active ulcerative colitis: a double-blinded randomized placebo-controlled clinical trial. J Crohns Colitis. 2014, 8:1498-1505. 10.1016/j.crohns.2014.06.001

22. Bourreille A, Cadiot G, Dreau G, et al.: Saccharomyces boulardii does not prevent relapse of Crohn's disease . Clin Gastroenterol Hepatol. 2013, 11:982-987. 10.1016/j.cgh.2013.02.021

23. Wildt S, Nordgaard I, Hansen U, Brockmann E, Rumessen JJ: A randomized double-blinded placebocontrolled trial with Lactobacillus acidophilus La- 5 and Bifidobacterium animalis subsp. lactis BB-12 for maintenance of remission in ulcerative colitis. J Crohns Colitis. 2011, 5:115-121.

10.1016/j.crohns.2010.11.004 


\section{Cureus}

24. Tursi A, Brandimarte G, Papa A, et al.: Treatment of relapsing mild-to-moderate ulcerative colitis with the probiotic VSL\#3 as adjunctive to standard pharmaceutical treatment: a double-blinded, randomized, placebo-controlled study. Am J Gastroenterol. 2010, 105:2218-2227. 10.1038/ajg.2010.218

25. Ng SC, Plamondon S, Kamm MA, et al.: immunosuppressive effects via human intestinal dendritic cells of probiotic bacteria and steroids in the treatment of acute ulcerative colitis. Inflamm Bowel Dis. 2010, 16:1286-1298. 10.1002/ibd.21222

26. Matthes H, Krummenerl T, Giensch M, Wolff C, Schulze J: Clinical trial: probiotic treatment of acute distal ulcerative colitis with rectally administered Escherichia coli Nissle 1917 (EcN). BMC Complement Altern Med. 2010, 10:13. 10.1186/1472-6882-10-13

27. Parker EA, Roy T, D'Adamo CR, Wieland LS: Probiotics and gastrointestinal conditions: an overview of evidence from the Cochrane collaboration. Nutrition. 2018, 45:125-134.e11. 10.1016/j.nut.2017.06.024

28. Clarke TC, Black LI, Stussman BJ, Barnes PM, Nahin RL: Trends in the use of complementary health approaches among adults: United States, 2002-2012. Natl Health Stat Report. 2015, 79:1-16.

29. Sartor RB: Efficacy of probiotics for the management of inflammatory bowel disease . Gastroenterol Hepatol (N Y). 2011, 7:606-608.

30. Nguyen GC, Loftus EV Jr, Hirano I, et al.: American Gastroenterology Association Institute guideline on the management of Crohn's disease after surgical resection. Gastroenterology. 2017, 152:271-275.

10.1053/i.gastro.2016.10.038 